\title{
A survey of the diversity of human enteric protoctistan parasites and the associated risk factors in urban Zvishavane, Zimbabwe
}

\author{
Masungo, Patience ${ }^{1}$, Dube, Trevor $^{1}$ and Makaka, Caston ${ }^{1 *}$ \\ ${ }^{1}$ Department of Biological Sciences, Midlands State University, Bag 9055. Gweru, Zimbabwe.
} ABSTRACT

\begin{abstract}
Community based survey of the diversity of human enteric protoctistan parasites was done on a random sample of 300 individuals in urban Zvishavane, Zimbabwe from December 2007 to May 2008. Stool, fruit, vegetable, water and pest sample specimens were analysed using the following techniques; permanent stains, microscopic analysis and the formol-ether concentration method. Stool specimen analysis showed that 98 individuals $(32.67 \%)$ of the population were infected with enteric protoctistan parasites. Infestation by Enterocytozoon bieneusi $(30.1 \%)$, Cryptosporidium parvum (18.4\%), Entamoeba histolytica (16.5\%), Encephalitozoon intestinalis $(14.6 \%)$, Cyclospora cayetanensis $(12.6 \%)$ and Giardia lamblia $(7.8 \%)$ were noted amongst the residents. The $20-35$ age group accounted for half $(47.96 \%)$ of the infections. Infection frequencies were higher in the high density areas (HDAs) than in the low density areas (LDAs). There were significant differences in infection levels between residents in southern and nothern HDAs $\left(t_{c}=3.226, p<0.01\right)$. However there were no significant differences in infection loads between southern and northern LDAs $\left(t_{c}=1.912, p>0.05\right)$. Risk factors included age, host density, pregnancy, infection by HIV or recent surgery. Improving the socio-economic conditions and raising awareness on issues related to intestinal parasitosis would aid in decreasing the infection levels in urban Zvishavane.
\end{abstract}

Keywords: parasites, enteric, protoctistan, diversity, infections, prevalence, risk factors, gastrointestinal tract.

\section{INTRODUCTION}

Intestinal parasitic infections are a major health problem in many developing countries. Factors contributing to this problem include geographic and socio-economic ones as well as unpredictable factors such as natural disasters. The optimum environmental conditions (such as temperature in water bodies) for the viability of the parasite infective forms are compounded by poverty, malnutrition, high population densities, lack of awareness on issues related to enteric parasite infections, low health status of individuals and the unavailability of potable water (WHO, 1998).

Ravdin (1988) as cited by Smyth (1996) stated that in developing countries, amoebiasis accounts for 450 million cases of enteric parasitosis per annum and about 100000 deaths. Insufficient research, lack of attention to issues pertaining to parasitic diseases and lack of follow up treatment are barriers to decreasing rates of parasite infection in most developing countries (Sayyari et al., 2005).

Much research has been done on the prevalence and diversity of enteric parasites in various countries (Stark et al., 2007, Oritz, 1980, Sayarri et al., 2005) but little has been done to determine the risk factors associated with parasite infections in the areas being investigated. In light of the problems the enteric protoctistan parasites pose to man, it is crucial to also investigate factors that shape the probability of acquiring parasite infection and the risk of developing pathology caused by the parasites. An integrated approach is vital for the efficient eradication of enteric parasitosis. Therefore, this study investigates the diversity of enteric parasites while at the same time determining the factors responsible for this diversity.

Study area: The study was carried out between December 2007 and May 2008, in Zvishavane town, Zimbabwe. It is at an altitude of $950 \mathrm{~m}$ (en.wikipedia.org/wiki/Zvishavane, Zimbabwe) and receives an average rainfall of below $500 \mathrm{~mm}$ per annum, most of it received during the rainy season (October-February). The rainy season is interspaced by dry spells and temperature ranges between $8^{\circ} \mathrm{C}$ $32^{\circ} \mathrm{C}$ with $30 \%$ relative humidity (Thurston, 1999).

There are ten residential areas in Zvishavane town. The residential areas are divided into northern and southern residential areas. In the north are the following low density residential areas; Mimosa park, 
Highlands, Highland extension, and Makwasha and one high density residential area; Mandava

To the south are the following low density residential areas; Ad valorem, Birthday and Surprise and the high density suburbs Nill Township and Kandodo

There is great spatial difference between these two groups of residential areas to warrant the possibility of different microclimates. Ideally the shortest distance between the southern and northern residential areas is approximately more than 15 kilometres. The northern residential areas are interspaced by vegetation thickets and there is rarely any raw sewerage seen from manholes, contrary to this scenario, some areas such as Makwasha and Mandava are strewn with raw sewerage which form rivulets that run parallel to the Gweru - Zvishavane road until they form a large pond just next to the Central Business District.

Ethical considerations: The importance of carrying out this study and the reason why the individuals were chosen for this exercise was explained to each individual. Though the study was non-invasive, informed consent was obtained from everyone or their parents in the case of children. Approval of undertaking such a study was granted by the District Medical Officer as well as the District Environmental Health Officer.

\section{METHODS}

A sample of 300 individuals was taken. This was achieved by randomly choosing 30 individuals from 30 randomly selected residential stands in each surburb. There was exclusion of individuals who were on anti-microbials within 2 weeks of the commencement of the study and during the study exercise. Exclusion of those on anti-acids such as bismuth, laxatives or water enema was also done because all these affect the presence of parasites in the gastro-intestinal tract.

Samples of stool, fruits, vegetables, water and insects were collected during the course of the study Data about age, sex, site of residence, co-existing conditions affecting the immune status and sources of water, were obtained by way of a structured, pretested questionnaire interview from each interviewee. The interviews were conducted in the privacy of the individuals' homes. Interviews were roughly five minutes long and each completed questionnaire was given a code number ranging from 1-300.

After conducting the interviews, individuals were given 3 specimen containers labelled with the same code number used on their questionnaire responses and advised on dates for stool specimen collection. The dates of submission of stools were the same for all the residential areas and the need for submission of specimen immediately after collection was emphasised. Stool specimen collection was done at the hospital ablution blocks to ensure prompt submission. Stools were collected on three consecutive days.

Qualitative and quantitative analysis of stools: Stools were initially scanned with the aid of a X5 hand magnifying glass for the presence of parasites other then protoctistan parasites. Wet mount preparations were then made by way of placing a drop of saline on a labelled microscope slide and then suspending a minute stool specimen in the drop of saline. A cover slip was placed over the drop, taking care to avoid air bubbles as these can sometimes be mistaken for cysts. Specimens were examined under the light microscope under the X10 objective lens and then under X40 objective lens. Identification of the different parasites was made with the aid of reference charts (Centre for disease control and prevention, 2001). Analysis of samples was done by the use of Modified Ziehl-Nelseen technique (Casemore, 1991) and Modified trichrome staining technique (Weber, 1992). In order to quantify the level of parasite infection in an individual, the formolether concentration technique was used (Suwansaksri et al., 2002).

Qualitative analysis of food samples: In order to establish the presence of protoctistan parasites in food sold at the Mandava open market, a variety of fruits and vegetables bought from the market were examined for the presence of enteric parasites using the magnesium sulphate flotation technique. Thirty out of the 98 available stalls were randomly selected. 10 samples of each of the fruit and vegetables were collected from the market. Fruits collected included; mangoes, apples, peaches and guavas while the vegetables included: black nightshade (Solanum nigrum), cabbage (Brassica oleracea capitata), rape and pumpkin leaves.

Pest analysis: To establish vectors of intestinal protoctistan parasites, homemade fly traps and a pooter were used to trap and collect insects from a total of 20 households; 2 households per residential area were randomly selected. Fly traps were made by cutting $500 \mathrm{ml}$ plastic bottles in half such that the top half can be inverted into the lower half. Two holes were perforated and string was laced through the holes such that the trap could be hung. 
Ripe bananas were used as bait. The bananas were peeled just before use and placed inside the traps. Trapping was done for 30 minutes around mid noon. Traps were then placed in ice chests for an hour to inactivate the flies before analysis in the lab. The exoskeleton, tarsi, setae and mouth parts were observed under a dissecting microscope to detect the presence of cysts and oocysts. None of the residents complained of rodents as pests, hence no effort was made to make traps for the rodents.

Water analysis: The municipality was the only source of potable water used by the residents. Every month, a volume of 10 litres of tap water was collected from one public tap in the central business district and analysed for enteric protoctistan parasites capable of infecting humans. Water was collected by heating the tap with an open flame for three minutes and then letting the water run for 5-10 seconds before collecting the water in autoclaved containers which were immediately closed.

The 10 litres of water was divided into (200) $50 \mathrm{ml}$ centrifugation tubes and centrifuged at 5000rpm after which aspiration was done to leave $1 \mathrm{ml}$ of water in each tube. The water in the tubes was transferred to fill four $50 \mathrm{ml}$ centrifugation tubes and centrifugation was repeated at $5000 \mathrm{rpm}$. The supernatant was aspirated to leave $1 \mathrm{ml}$ in each tube. The deposits were stained and analysed under the light microscope by a $\times 10$ objective lens then later a $\times 40$ objective lens.

Data analysis: $T$ test were perfomed to find out if there were any significant differences in infection intensities (mean oocyst/cyst counts per individual) between high density residential and low density residential areas and between northern and southern high density areas. The $X^{2}$ test of association was used to determine the risk factors associated with enteric protoctistan parasite infections.

\section{RESULTS}

Stool specimens: Successful stool collection was accomplished in 300 individuals divided amongst 164

Table 2. Distribution of enteric protoctistan parasites by age and sex

\begin{tabular}{|c|c|c|c|c|c|}
\hline Age & positive cases & $\begin{array}{l}\text { Females } \\
\% \text { of infection }\end{array}$ & positive cases & $\begin{array}{c}\text { Males } \\
\% \text { of total infection }\end{array}$ & Total \\
\hline$<5$ & 7 & 7.15 & 5 & 5.10 & 38 \\
\hline $5 \leq x<20$ & 4 & 4.08 & 4 & 4.08 & 62 \\
\hline $20 \leq x<35$ & 30 & 30.61 & 17 & 17.35 & 101 \\
\hline $35 \leq x<50$ & 15 & 15.31 & 12 & 12.24 & 62 \\
\hline$\geq 50$ & 3 & 3.06 & 1 & 1.02 & 37 \\
\hline Total & 59 & 60.21 & 39 & 39.79 & 30 \\
\hline
\end{tabular}

females and 136 males, hence a response rate was $100 \%$. Of these participants, $98(32.67 \%)$ were positive for enteric protoctistan parasites (Table 1). Though species from major taxa bearing human protoctistan parasites (microsporidia, apicomplexa, sarcomastigophora) were observed, no ciliates were observed.

Table 1. Diversity of enteric protoctistan parasites in the study population

\begin{tabular}{|l|l|l|}
\hline $\begin{array}{l}\text { Enteric protoctistan } \\
\text { parasite }\end{array}$ & $\begin{array}{l}\text { Number of } \\
\text { positive } \\
\text { cases }\end{array}$ & Percentage \\
\hline Entamoeba histolytica & 17 & 16.5 \\
\hline Giardia lamblia & 8 & 7.8 \\
\hline Cryptosporidium parvum & 19 & 18.4 \\
\hline Cyclospora cayetanensis & 13 & 12.6 \\
\hline Enterocytozoon bieneusi & 31 & 30.1 \\
\hline $\begin{array}{l}\text { Encephalitozoon } \\
\text { intestinalis }\end{array}$ & 15 & 14.6 \\
\hline TOTAL cases & $103^{*}$ & 100 \\
\hline & \multicolumn{2}{|l}{} \\
\hline
\end{tabular}

${ }^{* *}$ The difference between the number of positive individuals (98) and the actual number of parasite cases (103) is based on the fact that 5 of the individuals had compound infections (more than one parasite infection).

Most enteric parasitic infections were caused by Enterocytozoon bieneusi (30.1\%), followed by Cryptosporidium parvum and Entamoeba histolytica which constituted $18.5 \%$ and $16.5 \%$ of infections respectively. Giardia lamblia was responsible for the least infections (7.8\%), while Cyclospora cayetanensis represented $12.6 \%$ of the enteric

Distribution of parasitic infection by age and sex is shown in Table 2, below. 59 females $(60.21 \%$ of infected individuals) were infected with enteric protoctistan parasites as compared to only 39 males (39.79\%). Enteric protoctistian parasite infection were highest in the 20-35 age group for both sexes (30.61 for females and $17.35 \%$ for males) constituting nearly half $(47.96 \%)$ of the infections. parasites. 
The frequency and intensity of infection varied between residential areas. Infection frequency was higher in high density areas (Kandodo, Nil township and Mandava) than in low density residential areas (Ad Valorem, Birthday, Highlands, Highlands extension, Mimosa park, Makwasha and Surprise) (Fig 1).

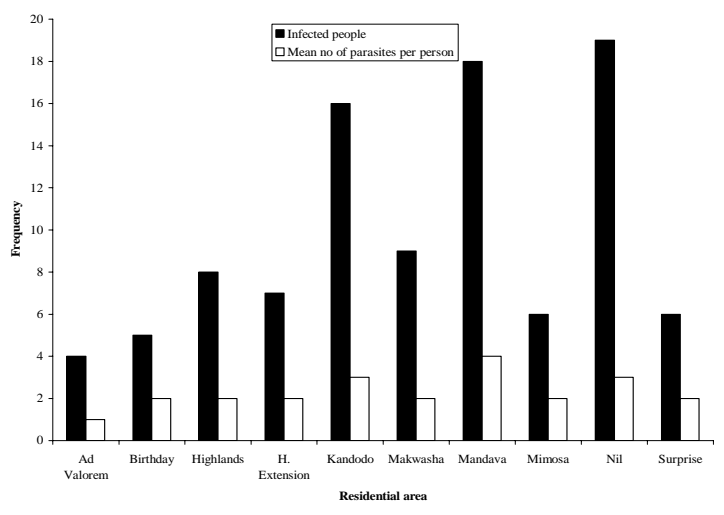

Fig 1. Frequency and infection intensity by enteric protoctistan parasites in residential areas.

Nil township, Mandava and Kandodo (high density areas) recorded the highest number of individuals with enteric parasite infections, (19, 18 and 16 respectively). Infection intensities (mean oocyst/cyst counts per individual) were also higher in the high density residential areas than the low density residential areas. There were significant differences in the infection intensities between northern and southern high density areas $\left(t_{c}=3.226, p<\right.$ $0.01)$. However there were no significant differences in infection intensities between northern and southern low density residential areas $(t=1.912, p>0.05)$

Fruits and vegetables: From the survey, 270 (90\% of sample population) buy fruits and vegetables at the Mandava market whereas only $10 \%$ of the study population relied on their backyard gardens for fruits and vegetables. Of the 270 participants who bought fruits and vegetables at Mandava market, 47 were infected with enteric protoctistan parasites while only 4 participants who relied on their backyard gardens were also infected with the parasites.

Fruits and vegetables sold at the market were infested with parasites which were capable of infecting the gastro-intestinal tract. Table 3 shows the infestation rates and the infecting enteric protoctists for the different fruits and vegetables.
Of all the fruits mangoes, had the highest infestation by protoctistan parasites whilst amongst the vegetables Solanum nigrum had the highest infestation by parasites $(60 \%)$.

Pests: The two main pests found in the households of the study population were cockroaches (Periplaneta americana) and flies (Musca domestica). A total of 96 insect pests were collected; of these 67 $(69.8 \%)$ were carriers of protoctistan parasites. Table 4 shows the percentages of insect pests that were carriers of enteric protoctistan parasites.

Table 3. Infestation rates of fruits and vegetables by protoctistan parasites

\begin{tabular}{|l|c|c|l|}
\hline $\begin{array}{l}\text { Vegetable/Fr } \\
\text { uit }\end{array}$ & $\begin{array}{c}\text { Infested } \\
\text { samples }\end{array}$ & $\begin{array}{c}\text { \% of } \\
\text { infestati } \\
\text { on per } \\
\text { species }\end{array}$ & Parasites \\
\hline $\begin{array}{l}\text { Cabbage } \\
\text { (Brassica } \\
\text { oleracea } \\
\text { capitata) }\end{array}$ & 5 & 50 & $\begin{array}{l}\text { microsporidia, } \\
\text { G.lamblia }\end{array}$ \\
\hline $\begin{array}{l}\text { rape } \\
\text { night }\end{array}$ & 3 & 30 & $\begin{array}{l}\text { microsporidia, } \\
\text { G.lamb }\end{array}$ \\
\hline $\begin{array}{l}\text { Black } \\
\text { shade } \\
\text { (Solanum } \\
\text { nigrum) }\end{array}$ & 4 & 60 & $\begin{array}{l}\text { E.histolytica } \\
\text { microsporidia }\end{array}$ \\
\hline $\begin{array}{l}\text { Pumpkin } \\
\text { leaves }\end{array}$ & 7 & 70 & $\begin{array}{l}\text { E.histolytica, } \\
\text { microsporidia }\end{array}$ \\
\hline Mangoes & 2 & 20 & $\begin{array}{l}\text { microsporidia, } \\
\text { G.lamblia }\end{array}$ \\
\hline Apples & 4 & 40 & E.histolytica \\
\hline Peaches & 2 & 20 & E.histolytica \\
\hline Avocadoes & & &
\end{tabular}

Table 4. Carriers of enteric protoctistan parasites

\begin{tabular}{|l|c|c|l|}
\hline Pest & $\begin{array}{c}\text { Number } \\
\text { analysed }\end{array}$ & $\begin{array}{l}\text { Carriers of } \\
\text { protoctista } \\
\text { n parasites }\end{array}$ & $\begin{array}{l}\text { As \% of } \\
\text { pest } \\
\text { species }\end{array}$ \\
\hline $\begin{array}{l}\text { Cockroaches } \\
\text { (Periplaneta } \\
\text { americana) }\end{array}$ & 59 & 42 & 71.19 \\
\hline $\begin{array}{l}\text { Flies (Musca } \\
\text { domestica) }\end{array}$ & 37 & 25 & 67.57 \\
\hline Total & 96 & 67 & \\
\hline
\end{tabular}

More than half of each pest species were carriers of protoctistan parasites capable of infecting the human gastro-intestinal tract. In Periplaneta americana, $71.19 \%$ of the sample specimens were noted as having cysts of Entamoeba histolytica on their setae. 
Musca domestica were noted to bear cysts of G.lamblia and oocysts of Cryptosporidium parvum on their proboscis and their tarsi. $67.57 \%$ of the Musca domestica were carriers of the cysts and oocyst, however the viability of these was not determined owing to lack of reagents.

Successful collection of pests was done in 12 households, 8 of these households had an individual whose stool specimen tested positive for enteric protoctistan parasites. No pests were obtained from 8 households. From the 8 households with no pests, 2 individuals had infestations of enteric protoctistan parasites (Table 5). Households with pests had a higher infection level of enteric protoctistan parasites than those without pests.

Table 5: Contingency table of the outcome of pest collection and infected individuals

\begin{tabular}{|l|c|c|c|}
\hline & $\begin{array}{c}\text { Households } \\
\text { with pests }\end{array}$ & $\begin{array}{c}\text { Households } \\
\text { without } \\
\text { pests }\end{array}$ & Total \\
\hline $\begin{array}{l}\text { Infected } \\
\text { individuals }\end{array}$ & 8 & 2 & 10 \\
\hline $\begin{array}{l}\text { Non-infected } \\
\text { individuals }\end{array}$ & 4 & 6 & 10 \\
\hline Total & 12 & 8 & 20 \\
\hline
\end{tabular}

Water specimens: All participants in the study used tap water. Cyst/oocyst counts over the study period were observed and noted as shown in Table 6. Parasites with the potential to inhabit the human $\mathrm{Gl}$ tract detected in the water included Cryptosporidium parvum oocysts and Giardia lamblia cysts. Cyst/oocysts decreased with progression towards the drier months of February, March, April and May, until there were virtually none that could be detected in the water. Out of the six water samples collected, only two contained oocysts/cysts and these were collected during the rainy season.

Table 6. Potential enteric protoctistan parasites in water

\begin{tabular}{|l|l|}
\hline Month & Parasite \\
\hline December & $\begin{array}{l}\text { Cryptosporidium } \\
\text { Giardia lamblia }\end{array}$ \\
\hline January & $\begin{array}{l}\text { Cryptosporidium } \\
\text { Giardia lamblia }\end{array}$ \\
\hline February & none \\
\hline March & none \\
\hline April & none \\
\hline May & none \\
\hline
\end{tabular}

\section{Risk factors associated with infection by enteric protoctistan parasites}

The risk factors associated with enteric protoctistan parasite infection in Zvishavane town include; age, host density and co-existing conditions affecting the immune system (Table 7).

Table 7. Risk factors, $X^{2}{ }_{c}$ values, degrees of freedom and $p$ values as generated by the $X^{2}$ of association at significance level of $5 \%$.

\begin{tabular}{|l|l|l|l|l|}
\hline Risk factor & $\mathbf{d f}$ & $\mathbf{X}^{2}{ }$ & $\mathbf{p}$ & $\begin{array}{l}\text { Conclu } \\
\text { sion }\end{array}$ \\
\hline Sex & 1 & 1.484 & $\mathrm{p}>0.05$ & $\mathrm{X}$ \\
\hline Age & 4 & 47.75 & $\mathrm{p}<0.05$ & + \\
\hline Vectors & 1 & 1.875 & $\mathrm{p}>0.05$ & $\mathrm{X}$ \\
\hline Host density & 1 & 38.5 & $\mathrm{p}<0.05$ & + \\
\hline Diet & 1 & 0.094 & $\mathrm{p}>0.05$ & $\mathrm{X}$ \\
\hline $\begin{array}{l}\text { Co-existing } \\
\text { condition affecting } \\
\text { immune system }\end{array}$ & 3 & 64.75 & $\mathrm{p}<0.05$ & + \\
\hline $\begin{array}{l}\text { Geographical } \\
\text { location }\end{array}$ & 1 & 0.015 & $\mathrm{p}>0.05$ & $\mathrm{X}$ \\
\hline
\end{tabular}

\section{DISCUSSION}

The study showed a very narrow diversity of enteric protoctistan parasites and the exclusion of all other forms of intestinal parasites suggesting that the principle of premonition was being observed (Smyth, 1996). This entails the inhibition of further infection by other parasites when already there is an existing stable population of parasites. Zvishavane being located on topography depicted by high terrain inclination is expected to have low diversity of parasites due to the fact that parasites especially those that have one or more free-living stages in the soil are more likely to be washed out of the soil as runoff (Patz et al., 2000)

Most of the parasites which were observed in the study are mainly associated with opportunistic infections related to HIV. These included microsporidia (Enterocytozoon bieneusi and Encephalitozoon intestinalis) which were responsible for $44.7 \%$ of enteric protoctistan parasitosis, 
Cryptosporidium parvum (18.4\%), E.histolytica $(16.5 \%)$, Cyclospora cayetanensis $(12.6 \%)$ and G.lamblia $(7.8 \%)$. These statistics were similar to statistics provided by PLWAH (2005). The 20-35 age group accounted for nearly half $(47.96 \%)$ of the enteric protoctistan parasite infections. These statistics are in consonance with the distribution of HIVIAIDS cases in various age groups in Zimbabwe (National AIDS Council of Zimbabwe, 2007).

Of great concern was the fact that only 5 stool specimens detected as having enteric protoctistan parasites were diarrhoeal in nature. This implied that parasitic infections in Zvishavane town were largely asymptomatic, creating a reservoir of enteric protoctistan parasites. If screening for enteric protoctistan parasites is not done, individuals in the community will remain ignorant about their status with regards to enteric parasitosis thus risking infecting others as well as re-infecting themselves

The high levels of infection in high density areas, ranging from $53.33 \%$ in Kandodo to $63.33 \%$ in Nil township were similar to those found in a study in San Juan Martinez (Escobedo, 2008). In this town in Cuba, host density was also a risk factor in enteric parasite infections, which is a similar scenario to Zvishavane town. The frequency of enteric protoctistan parasite infections in Zvishavane is comparable to findings of similar studies. In the Republic of Iran, intestinal protoctistan parasite infections affect a fifth of the population (Sayyari, 2005).

The high rate of pests which were observed as carriers of protoctistan parasites $(69.8 \%)$ was a pointer to the prevalence of unsanitary conditions in the environment (Greenberg, 1973). The epidemiological role of cockroaches was demonstrated in 1971 when Blatella germanica spread E.histolytica at their visited sites in India (Greenberg, 1973).

$41.25 \%$ of fruits and vegetables sold at the Mandava open market were infested with enteric protoctistan parasites. This indicated that food safety should be a public health priority in Zvishavane. There was also a need for education on food management and safety among the food handlers/vendors at the market. Among other actions that could be taken, the improvement of sanitary conditions in and around the market place could drastically reduce the infestation of foodstuffs by parasites. The risk of infection with intestinal parasites are increased when contaminated fruits and vegetables are eaten raw, undercooked to retain natural taste and preserve heat-liable nutrients such as vitamins.

Water in Zvishavane was generally clear of parasites except for the rainy season which coincided with part of the study period. This might have been a result of the increased turbidity of water which has an adverse impact on the water treatment efficacy (United States Environmental Protection Agency, 1999 ). The occurrence of Cryptosporidium parvum oocysts and G.lamblia cysts in water during the rainy season also suggested the contamination of the catchment area by either cattle manure or human excrement. This might require the use of filtration techniques combined with optimisation techniques such as flocculation in water treatment during the rainy season for the complete removal of parasites in the water. Considering the HIV statistics of the district, very low levels of parasites should be detected in the water at any one time. Infection doses as low as 1 Cryptosporidium parvum oocyst can elicit debilitating illness in the immuno-compromised individuals.

The location of the Shabanie mine hospital which provides health services to the people in the south is not readily accessible in terms of distance by the high density residents in the southern residential areas. This was due to the pre-1980 policies that were in place when the hospital was constructed, this created a situation whereby only the low density areas where in close proximity to the hospital. Dissemination of information related to intestinal parasitosis might be limited due to the location of the high residential areas, considering that distribution of pamphlets and health talks on various health issues are discussed at the hospital.

Risk factors associated with infection by enteric protoctistan parasites in Zvishavane such as the coexisting conditions affecting the immune system are largely due to the immune suppression by HIV. The statistics of age as a risk factor are generally not in consonance with the findings from similar studies. In the United States of America the $<5$ age group is affected the most by enteric protoctistan parasites such as G.lamblia (United States Environmental Protection Agency, 1999).

Though there is a narrow diversity of protoctistan parasites in Zvishavane, the level of infections by these parasites were high enough to warrant action on the part of relevant authorities. The main areas of concern when tackling the issue of enteric parasitosis 
would be issues associated with sanitary conditions and trying to lessen the density of individuals in residential areas.

In conclusion, this survey has shown that the enteric protoctistan parasites found in Zvishavane are Entamoeba histolytica, Giardia lamblia, Enterocytozoon bieneusi, Encephalitozoon intestinalis, Cryptosporidium parvum and Cyclospora cayetanensis. The risk factors associated with their infection include; age. host density and co-existing conditions associated with the suppression of the immune system.

Prevention is largely implemented by techniques which seek to improve sanitary conditions as well as socio-economic conditions which aim to reduce the density of individuals residing within a particular area. Awareness on issues related to enteric parasites is a major tool in fighting parasitosis in the developing countries.

The following may be done to prevent infection by enteric protoctistan parasites and all other intestinal parasites; Discourage communal hand washing, regular medical examinations should be done on all food handlers by the local authorities, water should be boiled before drinking no matter how clear it looks, avoid the use of untreated human excrement in vegetable gardens, efficient pest control should be carried out and inspection of all premises where food is sold and stored.

Observing these guidelines may drastically reduce the levels of infection by enteric protoctistan parasites in Zvishavane.

\section{REFERENCES}

Casemore D.P. ACP Broadsheet 128, (1991); Laboratory methods for diagnosing cryptosporidiosis

Centre for disease control. (2001), DPDx : Laboratory identification of parasites of public health concern, State printers, Atlanta.

Escobedo AA, Canete R and Nunez, F A (2008). Prevalence and clinical features associated with intestinal parasite infections in children in San Juan Martinez, Cuba, West Indian J. vol 57: 4, 69-74
Greenberg B (1973). Flies and diseases, Princeton University press, New Jersey.

*http://en.wikipedia.org/Amoebiasis

http:// www.enwiki/Zvish

*http://umm.edu

National AIDS council of Zimbabwe, Annual report on AIDS statistics (2007). Longman, Harare

Oritz JS (1980). The prevalence of intestinal parasites in Puerto Rican farm workers in western Massacheusetts, Amer. J. of Public health, 70: 11031105.

Patz J A, Graczyk T K, Geller N and Vittor A . (2000). Effects of environmental change on emerging parasite diseases, International J. of Paras, 30: 1395-1405

People living with AIDS and HIV in Zimbabwe (2005) PLWAH report, Mambo press, Gweru, Zimbabwe.

Sayarri AA, Imanzadeh F and Karani H (2005). Prevalence of intestinal parasitic infections in the Islamic Republic of Iran, Eastern Mediterranean Health J., 11: article 3, pp 891-894.

Smyth JD (1996). Animal parasitology, Cambridge low price edition, Cambridge University Press, Cambridge.

Stark D, Fotedar R, Van Haus S, Harness J and Marriott D (2007). Prevalence of enteric protozoain human immunodeficiency virus positive and negative men who have sex with men from Sydney, Australia, Ameri J. of Trop Hyg, 76: article 3, pp 549-552

Suwansaksri J, Nithiuthai S, Wiwanitkt V, Soogarrun S and Palatho P (2002). The formol-ether concentration technique for intestinal parasites: comparing $0.1 \mathrm{~N}$ sodium hydroxide with normal saline preparations. Southeast Asian J. Trop. Med. Public Health. 33 Suppl 3:97-8.

Thurston $P$ (1999). A guide to touring southern Africa, 2nd Edition, Mambo press, Gweru, Zimbabwe.

United States Environmental Protection Agency (1999). Giardia, State press, Washington DC.

World Health Organisation (1998).World health reports, Life in the $21^{\text {st }}$ century a vision for all, Geneva

Weber R et al (1992) Improved light-micriscopical detection of Microsporidia spores in stool and duodenal aspiarates. New Eng. J. Med 326 (3): 161 - 166

Zvishavane district hospital (1998-2007). Stool microscopy registers. 